\title{
Influence of the Dimensional Change, and Its Dispersion, on the Fabrication Size Tolerances of Austempered Ductile Iron (ADI) Parts: Comparison with SAE 4140 Steel
}

\author{
María D. ECHEVERRÍA, Osvaldo J. MONCADA and Jorge A. SIKORA \\ INTEMA, Faculty of Engineering, National University of Mar del Plata, Juan B. Justo 4302, (7600) Mar del Plata, Argentina. \\ E-mail: jsikora@fi.mdp.edu.ar.
}

(Received on April 17, 2000; accepted in final form on September 22, 2000)

\begin{abstract}
To accurately satisfy the size tolerance of metallic parts, it is necessary to take into account the dimensional change $(D C)$ caused by heat treatment, and the dispersion $(\triangle D C)$ of the $D C$ values. The information available on this topic for ADI is very scarce.

The present work aims to determine $D C$ and $\triangle D C$ on $A D I$ and SAE 4140 steel parts and to analyze its influence on the size tolerances. Ductile iron and SAE 4140 steel specimens were used to compare $D C$ and $\triangle D C$ caused by austempering, and quenching and tempering heat treatments. $D C$ and $\triangle D C$ were also measured for several industrial parts of different ADI grades, having different chemical compositions, shapes and sizes.

The results show that in average ADI suffer greater DC than SAE 4140 steel parts of similar mechanical properties, but, on the other hand, $\triangle D C$ is always lower for $A D I$ than for steel.

A more accurate prediction of the $D C$ is then possible on ADI than on steels. This would allow the use of less strict machining tolerances, under better machinability conditions, when final operations can be done before heat treatment, producing series of ADI parts. This represents a technical and economical advantage for ADI in comparison with steel.

The influence that the previous microstructure, the austempering temperature and the piece anisotropy, exert on the $D C$ of $A D I$ were also studied. The effects identified in this work are in agreement with previously reported results.
\end{abstract}

KEY WORDS: dimensional change; dispersion of dimensional change; ADI and SAE 4140 steel; fabrication and machining tolerances; fabrication steps.

\section{Introduction}

The dimensional change $(D C)$ caused by heat treatment of ductile iron and steel parts, is an important factor that must be taken into account to enable the final piece dimensions to be within the required size tolerance.

There is information in handbooks that allows to predict accurately $D C$ of some steels. ${ }^{1}$ This is not the case for Austempered Ductile Iron (ADI). $D C$ in ADI is difficult to predict because many variables affect its magnitude, and the available information is very scarce. ${ }^{2-4)}$ By the other hand, the machinability rating of ADI is lower than that of as-cast ductile iron, ${ }^{5,6)}$ and in consequence longer cutting time and higher cost must be considered if machining is to be done after heat treatment.

In a previous work, the authors of the present article pointed out the principal factors affecting $D C$, and gave quantitative information about its values for different ADI grades. ${ }^{7)}$ Complementary, the $D C$ of many ADI industrial parts developed by the research group was systematically measured, and the results were introduced in a data base which helps in the prediction of $D C$ of new ADI pieces.

To define correctly the fabrication sequence of an ADI part, to be produced in a serial process, and to accurately establish its machining tolerance, it is necessary to take into account the dispersion of the $D C$ values.

In fact, if the final machining of a piece is carried out before heat treatment, the predicted $D C$ must be compensated by adjusting the nominal size $(X)$, reaching the nominal machining size $(\mathrm{Xm})$.

As it is indicated in Fig. 1-a), for $D C>0$ it results:

$$
X m=X-D C
$$

In a serial production process the $D C$ of a part can vary within a range, which amplitude is defined as the dispersion of dimensional change $(\triangle D C)$ (see Fig. 1-b).

In order to satisfy the size tolerance $(T)$ (Fig. 1-c), the values of $\triangle D C$ must be considered to obtain the machining tolerance $(\mathrm{Tm})$, indicated in Fig. 1-d, using the following expression:

$$
T m=T-\Delta D C
$$


Equation (2) means that when the smaller the value of $\Delta D C$ the larger the value of $T m$, and in consequence the lower the precision requirements in the machining operations.

It is important to point out that $D C$ only influences the magnitude of $X m$, while $\triangle D C$ directly affects $T m$, and in consequence the machining operation cost. For this reason it is desirable that $\triangle D C$ remains as small as possible. The influence of $D C$ and $\triangle D C$ on the size tolerance of ADI and cast steel parts has not been analyzed in the literature, to the best of our knowledge.

Taking into account that many ADI parts could be also produced in heat treated SAE 4140 steel, because both materials cover similar fields of applications, the comparison of $D C$ and $\triangle D C$ between them results of industrial interest.

The principal objectives of the present work are: a) To determine $D C$ and $\triangle D C$ on ADI industrial parts, and experimental specimens of ADI and SAE 4140 steel of similar mechanical properties. b) To analyze the variables affecting $D C$ in test specimens and industrial parts, and to compare them with other reported values.

\section{Experimental Procedure}

\subsection{Specimens}

Cylindrical bars of $11.5 \mathrm{~mm}$ diameter and $108 \mathrm{~mm}$ length were machined from "Y" blocks (ASTM A395) of ductile iron, and SAE 4140 cast steel, produced by industrial foundries by using conventional casting practices.

The chemical composition [wt $\%$ ] of the ductile iron used was: $\mathrm{C}=3.40, \mathrm{Si}=2.77, \mathrm{Mn}=0.45, \mathrm{Cu}=1.17, \mathrm{Ni}=1.43$, $\mathrm{Mo}=0.18, \mathrm{P}=0.01, \mathrm{~S}=0.01$, and $\mathrm{Mg}=0.04$. The as-cast microstructure was predominantly pearlitic.

The chemical composition [wt $\%$ ] of the cast steel was: $\mathrm{C}=0.43, \mathrm{Si}=0.36, \mathrm{Mn}=0.86, \mathrm{Cr}=1.05, \mathrm{Mo}=0.22, \mathrm{P}=$

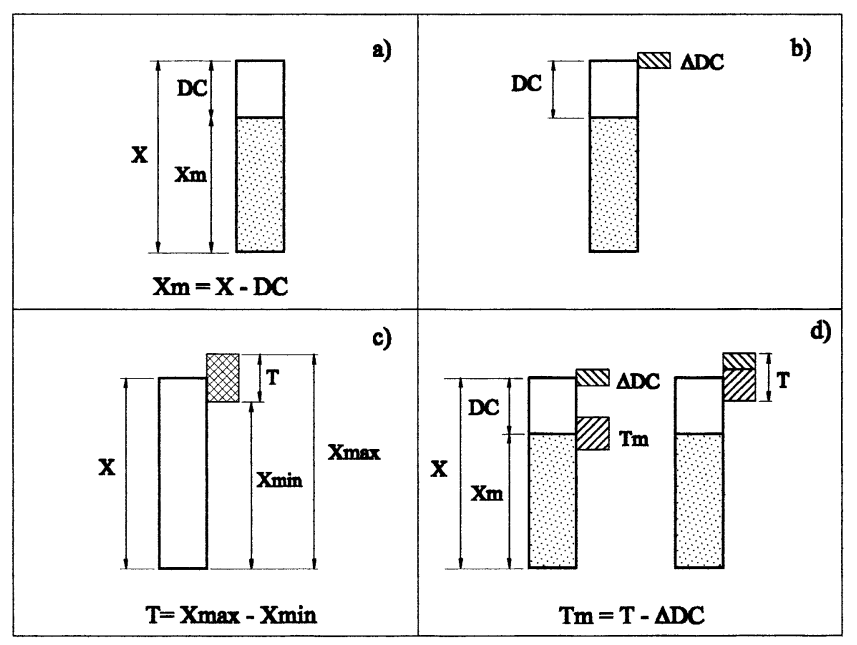

Fig. 1. Influence of $D C$ and $\triangle D C$ on the piece dimensions and the machining tolerance. $1-a$, correction taking into account $D C$; 1-b, standard deviation $\triangle D C ; 1$-c, size tolerance $(T) ; 1-\mathrm{d}$, machining tolerance $(\mathrm{Tm})$.
$0.027, \mathrm{~S}=0.025$. It is important to point out that the steel was annealed by the steel foundry before delivery, and showed ferritic-pearlitic microstructure. Therefore, the dimensional change measured on the steel is that taking place as a result of the quenching and tempering of an annealed condition, and not of an as-cast condition.

The ductile iron specimens were heat treated to obtain two different ADI grades (grades 2 and 5 of ASTM 89790), using the austenitizing and austempering temperatures and times indicated in Table 1.

The steel specimens were quenched in oil, and then tempered in order to obtain two different conditions (T1 and T2), as it is indicated in Table 2.

Table 3 lists the mechanical properties measured after heat treatment. The ADI grade 2 specimens have similar hardness and tensile strength than the steel with the heat treatment indicated as T1 in Table 2. A similar comparison can be done between ADI grade 5 and the steel treated according to $\mathrm{T} 2$.

\subsection{ADI Industrial Parts}

The chemical composition and predominant as cast microstructures of the industrial parts, are indicated in Table 4.

Four basic shapes can be recognized as follows:

a) Tubes (internal gears of four different sizes) Fig. 2-a)

b) Plate cams: (thin cams with similar sizes) Fig. 2-b)

c) Rectangular bars: (mill blades with similar sizes) Fig. 2c)

d) Disks with hub: (thin, medium and thick ) Fig. 2-d)

The austenitizing and austempering temperatures and times, used for the heat treatment of the parts, are indicated in Table 5.

\subsection{Measuring Method}

All industrial parts and specimens were carefully measured before and after heat treatment in order to determine the $D C$. A Coordinate Measuring Machine, with a linear displacement accuracy of $2.5+4 \mathrm{~L} / 1000 \mu \mathrm{m}$, and a Measuring Repeatability of $4 \mu \mathrm{m}$ was used.

The number of samples, necessary to obtain comparative results, was determined using statistical analysis. An

Table 1. Experimental specimens of ADI: Thermal cycles.

\begin{tabular}{|c|c|c|}
\hline Material & ADI grade 2 & ADI grade 5 \\
\hline Austenitizing & $900^{\circ} \mathrm{C}-60^{\prime}$ & $920^{\circ} \mathrm{C}-60^{\prime}$ \\
\hline Austempering & $360^{\circ} \mathrm{C}-90^{\prime}$ & $280^{\circ} \mathrm{C}-120^{\prime}$ \\
\hline
\end{tabular}

Table 2. Experimental specimens of SAE 4140 steel: Thermal cycles.

\begin{tabular}{|c|c|c|}
\hline Heat-treatment & $\mathrm{T} 1$ & $\mathrm{~T} 2$ \\
\hline Quenching & $850^{\circ} \mathrm{C}-60^{\prime}$ & $850^{\circ} \mathrm{C}-60^{\prime}$ \\
\hline Tempering & $620^{\circ} \mathrm{C}-60^{\prime}$ & $445^{\circ} \mathrm{C}-60^{\prime}$ \\
\hline
\end{tabular}

Table 3. Mechanical properties of experimental specimens

\begin{tabular}{|l|c|c|c|c|}
\hline \multicolumn{1}{|c|}{ Propertie } & ADI Grade 2 & ADI Grade 5 & SAE 4140 T1 & SAE 4140 T2 \\
\hline Tensile strength $\sigma_{R}[\mathrm{Mpa}]$ & 1133 & 1450 & 1180 & 1530 \\
\hline Hardness $[\mathrm{HRC}]$ & 38 & 47 & 36 & 46 \\
\hline
\end{tabular}


Table 4. As-cast microstructure and chemical composition of industrial parts.

\begin{tabular}{|lr|c|c|c|c|c|c|}
\hline \multicolumn{2}{|c|}{ PART / TIPE (*) } & Microstructure & $\mathrm{Mn}$ & $\mathrm{Cu}$ & $\mathrm{Ni}$ & $\mathrm{Mo}$ & $\mathrm{Si}$ \\
\hline Internal gears I & (a) & Ferritic & 0.5 & $<0.10$ & $<0.10$ & $<0.10$ & 2.96 \\
\hline Internal gears II and IV (a) & Pearlitic-ferritic & 0.29 & 0.49 & 0.69 & 0.12 & 3.26 \\
\hline Internal gears III & (a) & Pearlitic-ferritic & 0.27 & 0.47 & 0.66 & 0.18 & 3.17 \\
\hline Plate Cams & (b) & Pearlitic-ferritic & 0.31 & 0.98 & 1.06 & 0.18 & 2.68 \\
\hline Mill blades I & (c) & Pearlitic-ferritic & 0.36 & 0.82 & 0.50 & 0.14 & 3.06 \\
\hline Mill bladesII & (c) & Pearlitic-ferritic & 0.36 & 0.82 & 0.50 & 0.14 & 3.06 \\
\hline Mill blades III & (c) & Pearlitic-ferritic & 0.27 & 0.47 & 0.66 & 0.12 & 2.95 \\
\hline Disks with hub, thins (d) & Pearlitic & 0.36 & 1.19 & 0.58 & 0.23 & 2.59 \\
\hline Disks with hub, mediums (d) & Pearlitic-ferritic & 0.36 & 1.19 & 0.58 & 0.23 & 2.59 \\
\hline Disks with hub, thicks (d) & Ferritic-pearlitic & 0.36 & 1.19 & 0.58 & 0.23 & 2.59 \\
\hline
\end{tabular}
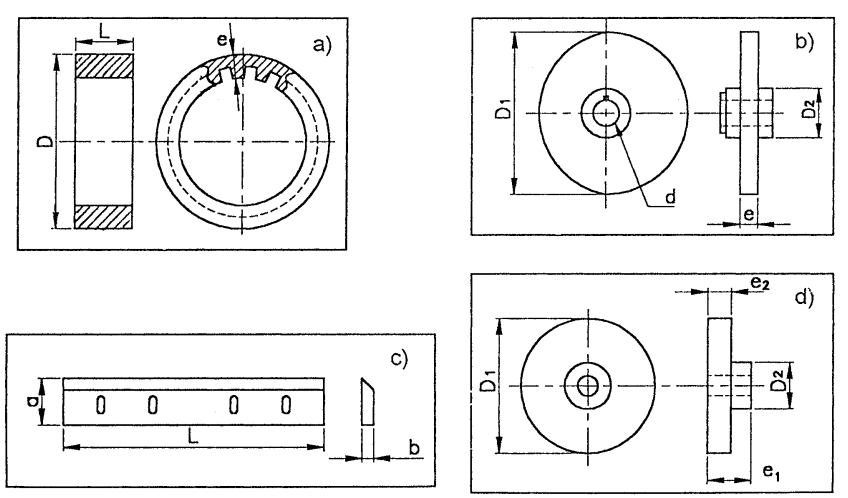

Fig. 2. Basic shapes of industrial parts: a) tubes (internal gears), b) plate cams, c) rectangular bars (mill blades), d) disks with hub.

Table 5. Industrial parts: Thermal cycles.

\begin{tabular}{|l|c|c|c|}
\hline \multicolumn{1}{|c|}{ PART } & Austenitizing & Austempering & ADI Grade \\
\hline Internal gears I & $910^{\circ} \mathrm{C}-90^{\prime}$ & $300^{\circ} \mathrm{C}-120^{\prime}$ & 2 \\
\hline Internal gears II to IV & $910^{\circ} \mathrm{C}-90^{\prime}$ & $310^{\circ} \mathrm{C}-90^{\prime}$ & 2 \\
\hline Plate cams & $920^{\circ} \mathrm{C}-120^{\prime}$ & $280^{\circ} \mathrm{C}-120^{\prime}$ & 3 \\
\hline Mill blades I & $920^{\circ} \mathrm{C}-120^{\prime}$ & $260^{\circ} \mathrm{C}-120^{\prime}$ & 4 \\
\hline Mill blades II & $920^{\circ} \mathrm{C}-120^{\prime}$ & $220^{\circ} \mathrm{C}-120^{\prime}$ & 5 \\
\hline Mill blades III & $920^{\circ} \mathrm{C}-180^{\prime}$ & $270^{\circ} \mathrm{C}-90^{\prime}$ & 4 \\
\hline Disks with hub (all of them) & $900^{\circ} \mathrm{C}-60^{\prime}$ & $360^{\circ} \mathrm{C}-90^{\prime}$ & 1 \\
\hline
\end{tabular}

amount of $n=10$ industrial parts, or test specimens, was adopted for each variable studied (chemical composition, microstructure, shape, size and austempering temperature).

The percent Dimensional Change, $(D C i \%)$, of each specimen or part dimension $(X)$, was calculated using the measured actual values before $(X o)$, and after $(X f)$ heat treatment, following the expression:

$$
D C i \%=100[(X f-X o) / X o]
$$

The average Dimensional Change, $D C \%$, of any dimension of a batch of $n$ pieces, was calculated as:

$$
D C \%=\sum_{i=1}^{n}(D C i \%) / n
$$

and the standard deviation $\triangle D C \%$, as:

$$
\Delta D C=\sqrt{\sum_{i=1}^{n}\left[(D C i \%-D C \%)^{2}\right] / n}
$$

The values of $\triangle D C$, used to calculate the machining toler- ances $T m$, are expressed in units of length, $[\mathrm{mm}]$ or $[\mu \mathrm{m}]$, as follows:

$$
\Delta D C[\mathrm{~mm}]=X o \Delta D C \% / 100
$$

\section{Results and Discussion}

\section{1. $D C$ and $\triangle D C$ in Industrial ADI Parts}

Table 6 lists the results of $D C \%$ and $\triangle D C \%$ for the different industrial ADI parts, previously described in Fig. 2 and Tables 4 and 5.

The $D C$ values, as a consequence of the different chemical composition, heat treatment cycles, shape, microstructure, etc., show important differences, ranging from 0.04 to $0.53 \%$, for the different parts. Nevertheless the values of $\triangle D C$ were consistently small, and they fluctuate within a narrow range. The exception are those values corresponding to the smaller measured dimensions, where the higher fluctuation can be attributed to a larger influence of the measuring error (for example in the case of thickness of internal gears II, III and IV reported in Table 4).

Table 6 lists the values of $\Delta D C[\mu \mathrm{m}]$ calculated by using Eq. (6).

The machining tolerance $(T m)$, which could be obtained when using CNC lathes (accuracy: $\pm 5 \mu \mathrm{m}$ ) or $\mathrm{CNC}$ Machining Centers (accuracy: $\pm 15 \mu \mathrm{m}$ ) compatible with the machining equipment, must be added to the $\triangle D C$ value in order to calculate the minimum size tolerance ( Tmin).

Table 6 also lists the equivalent IT ISO standard tolerance grades, ${ }^{7)}$ in correspondence with the mentioned Tmin values.

\section{2. $D C$ and $\triangle D C$ for Experimental Specimens of $A D I$ and SAE 4140 Steel}

Table 7 shows the results of $D C \%$ and $\triangle D C \%$ for the length and diameter of the ADI and SAE 4140 steel specimens, previously indicated in Tables 1 and 2 .

Figure 3 shows the values of $D C \%$ and $\triangle D C \%$ for the length of ADI and steel specimens. Figure 3(a) corresponds to ADI grade 2 and SAE 4140 steel with heat treatment identified as T1 (Table 2). Figure 3(b) compares the values for ADI grade 5 and the steel with treatment T2.

The results show that the dimensional changes are higher for ADI than for steel. This only implies that the nominal machining size $X m$ (Fig. 1-a) must be different for each material, but it does not influence the machining tolerance (Tm) (Fig. 1-d), because $T m$ is independent from $D C$, and is 
Table 6. Average results of $D C$ and $\triangle D C$ of industrial parts. IT-ISO tolerance grades obtainable by CNC machining processes.

\begin{tabular}{|c|c|c|c|c|c|c|c|c|c|c|}
\hline \multirow[t]{2}{*}{ Part } & \multicolumn{2}{|l|}{ Dimension } & \multirow[t]{2}{*}{$\begin{array}{l}\mathrm{DC} \\
{[\%]}\end{array}$} & \multirow[t]{2}{*}{$\begin{array}{c}\Delta D C \\
{[\%]}\end{array}$} & \multirow[t]{2}{*}{$\begin{array}{r}\Delta D C \\
6[\mu \mathrm{m}]\end{array}$} & \multicolumn{2}{|c|}{$\begin{array}{c}\text { Minimum size } \\
\text { tolerance (Tmin) } \\
6[\mu \mathrm{m}]\end{array}$} & \multicolumn{2}{|c|}{$\begin{array}{c}\text { Equivalent IT ISO } \\
\text { standard } \\
\text { tolerance grade }\end{array}$} & \multirow[t]{2}{*}{$\begin{array}{c}\text { ADI } \\
\text { Grade }\end{array}$} \\
\hline & Type & {$[\mathrm{mm}]$} & & & & CNC-L & CNC-MC & CNC-L & CNC-MC & \\
\hline $\begin{array}{l}\text { Internal } \\
\text { Gears I }\end{array}$ & $\begin{array}{l}\text { Length (L) } \\
\text { Ext. Dia. (D) }\end{array}$ & $\begin{array}{c}53 \\
105\end{array}$ & $\begin{array}{l}0.087 \\
0.056\end{array}$ & $\begin{array}{l}0.012 \\
0.014\end{array}$ & $\begin{array}{c}6 \\
15\end{array}$ & $\begin{array}{l}11 \\
20\end{array}$ & - & $\begin{array}{l}7 \\
8\end{array}$ & - & 2 \\
\hline $\begin{array}{l}\text { Internal } \\
\text { Gears II }\end{array}$ & $\begin{array}{l}\text { Thickness (e) } \\
\text { Length (L) } \\
\text { Ext. Dia. (D) }\end{array}$ & $\begin{array}{c}9.5 \\
58 \\
105\end{array}$ & $\begin{array}{l}0.371 \\
0.187 \\
0.230\end{array}$ & $\begin{array}{l}0.041 \\
0.042 \\
0.049\end{array}$ & $\begin{array}{c}4 \\
24 \\
51\end{array}$ & $\begin{array}{c}9 \\
29 \\
56\end{array}$ & $\begin{array}{l}\overline{-} \\
-\end{array}$ & $\begin{array}{c}8 \\
9 \\
10\end{array}$ & $\begin{array}{l}- \\
-\end{array}$ & 2 \\
\hline $\begin{array}{l}\text { Internal } \\
\text { Gears III }\end{array}$ & $\begin{array}{l}\text { Thickness (e) } \\
\text { Length (L) } \\
\text { Ext. Dia. (D) }\end{array}$ & $\begin{array}{l}9.5 \\
82 \\
105\end{array}$ & $\begin{array}{l}0.302 \\
0.237 \\
0.221\end{array}$ & $\begin{array}{l}0.050 \\
0.034 \\
0.026\end{array}$ & $\begin{array}{c}5 \\
28 \\
27\end{array}$ & $\begin{array}{l}10 \\
33 \\
32 \\
\end{array}$ & $\begin{array}{l}- \\
- \\
-\end{array}$ & $\begin{array}{l}8 \\
9 \\
9\end{array}$ & $\begin{array}{l}- \\
-\end{array}$ & 2 \\
\hline $\begin{array}{l}\text { Internal } \\
\text { Gears IV }\end{array}$ & $\begin{array}{l}\text { Thickness (e) } \\
\text { Length (L) } \\
\text { Ext. Dia. (D) }\end{array}$ & $\begin{array}{c}9.5 \\
38 \\
105 \\
\end{array}$ & $\begin{array}{l}0.405 \\
0.193 \\
0.222 \\
\end{array}$ & $\begin{array}{l}0.070 \\
0.034 \\
0.041\end{array}$ & $\begin{array}{c}7 \\
13 \\
43 \\
\end{array}$ & $\begin{array}{l}12 \\
18 \\
48\end{array}$ & $\begin{array}{l}- \\
- \\
-\end{array}$ & $\begin{array}{c}9 \\
8 \\
10\end{array}$ & - & 2 \\
\hline $\begin{array}{l}\text { Plate } \\
\text { Cams }\end{array}$ & $\begin{array}{l}\text { Thickness (e) } \\
\text { Hole Dia. (d) } \\
\text { Hub Dia. }\left(D_{2}\right) \\
\text { Ext. Dia. }\left(D_{1}\right)\end{array}$ & $\begin{array}{c}22 \\
44 \\
80 \\
263 \\
\end{array}$ & $\begin{array}{l}0.425 \\
0.344 \\
0.370 \\
0.367\end{array}$ & $\begin{array}{l}0.030 \\
0.025 \\
0.010 \\
0.013 \\
\end{array}$ & $\begin{array}{c}7 \\
11 \\
8 \\
34 \\
\end{array}$ & $\begin{array}{l}12 \\
16 \\
13 \\
- \\
\end{array}$ & $\begin{array}{l}- \\
- \\
- \\
49\end{array}$ & $\begin{array}{l}8 \\
8 \\
7 \\
- \\
\end{array}$ & $\begin{array}{l}- \\
- \\
9\end{array}$ & 3 \\
\hline $\begin{array}{l}\text { Disks } \\
\text { With hub } \\
\text { Thins }\end{array}$ & $\begin{array}{l}\text { Thickness disk }\left(e_{2}\right) \\
\text { Thickness hub }\left(e_{1}\right) \\
\text { Hub Dia. }\left(D_{2}\right) \\
\text { Ext. Dia. }\left(D_{1}\right)\end{array}$ & $\begin{array}{c}10 \\
25 \\
53 \\
147\end{array}$ & $\begin{array}{l}0.373 \\
0.432 \\
0.236 \\
0.275\end{array}$ & $\begin{array}{l}0.018 \\
0.017 \\
0.020 \\
0.010\end{array}$ & $\begin{array}{c}2 \\
4 \\
10 \\
15\end{array}$ & $\begin{array}{c}7 \\
9 \\
15 \\
20\end{array}$ & $\begin{array}{l}- \\
- \\
-\end{array}$ & $\begin{array}{l}7 \\
7 \\
7 \\
7\end{array}$ & $\begin{array}{l}- \\
- \\
-\end{array}$ & 1 \\
\hline $\begin{array}{c}\text { Disks } \\
\text { With hub } \\
\text { Mediums }\end{array}$ & $\begin{array}{l}\text { Thickness disk }\left(e_{2}\right) \\
\text { Thickness hub }\left(e_{1}\right) \\
\text { Hub Dia. }\left(D_{2}\right) \\
\text { Ext. Dia. }\left(D_{1}\right)\end{array}$ & $\begin{array}{c}21 \\
47 \\
54 \\
148 \\
\end{array}$ & $\begin{array}{l}0.163 \\
0.191 \\
0.102 \\
0.085 \\
\end{array}$ & $\begin{array}{l}0.027 \\
0.027 \\
0.017 \\
0.013 \\
\end{array}$ & $\begin{array}{c}6 \\
13 \\
9 \\
19 \\
\end{array}$ & $\begin{array}{l}11 \\
18 \\
14 \\
24 \\
\end{array}$ & $\begin{array}{l}- \\
- \\
- \\
-\end{array}$ & $\begin{array}{l}8 \\
8 \\
7 \\
8 \\
\end{array}$ & $\begin{array}{l}- \\
- \\
- \\
\end{array}$ & 1 \\
\hline $\begin{array}{l}\text { Disks } \\
\text { With hub } \\
\text { Thicks }\end{array}$ & $\begin{array}{l}\text { Thickness disk }\left(e_{2}\right) \\
\text { Thickness hub }\left(e_{1}\right) \\
\text { Hub Dia. }\left(D_{2}\right) \\
\text { Ext. Dia. }\left(D_{1}\right)\end{array}$ & $\begin{array}{c}40 \\
82 \\
53 \\
147 \\
\end{array}$ & $\begin{array}{l}0.042 \\
0.100 \\
0.077 \\
0.038 \\
\end{array}$ & $\begin{array}{l}0.017 \\
0.010 \\
0.021 \\
0.014 \\
\end{array}$ & $\begin{array}{c}7 \\
8 \\
11 \\
21 \\
\end{array}$ & $\begin{array}{l}12 \\
13 \\
16 \\
26 \\
\end{array}$ & $\begin{array}{l}- \\
- \\
- \\
-\end{array}$ & $\begin{array}{l}7 \\
7 \\
8 \\
8 \\
\end{array}$ & $\begin{array}{l}- \\
- \\
- \\
-\end{array}$ & 1 \\
\hline $\begin{array}{c}\text { Mill } \\
\text { Blades I }\end{array}$ & $\begin{array}{c}\text { Thickness (b) } \\
\text { Width (a) } \\
\text { Length (L) }\end{array}$ & $\begin{array}{c}18 \\
62 \\
360 \\
\end{array}$ & $\begin{array}{l}0.532 \\
0.432 \\
0.475 \\
\end{array}$ & $\begin{array}{l}0.030 \\
0.010 \\
0.032 \\
\end{array}$ & $\begin{array}{c}5 \\
6 \\
115 \\
\end{array}$ & - & $\begin{array}{c}20 \\
21 \\
130 \\
\end{array}$ & - & $\begin{array}{c}9 \\
8 \\
11 \\
\end{array}$ & 4 \\
\hline $\begin{array}{c}\text { Mill } \\
\text { Blades II }\end{array}$ & $\begin{array}{c}\text { Thickness (b) } \\
\text { Width (a) } \\
\text { Length (L) }\end{array}$ & $\begin{array}{r}18 \\
62 \\
360 \\
\end{array}$ & $\begin{array}{l}0.440 \\
0.412 \\
0.416\end{array}$ & $\begin{array}{l}0.030 \\
0.017 \\
0.021\end{array}$ & $\begin{array}{c}5 \\
11 \\
76\end{array}$ & $\begin{array}{l}- \\
-\end{array}$ & $\begin{array}{l}20 \\
26 \\
91\end{array}$ & $\begin{array}{l}- \\
- \\
-\end{array}$ & $\begin{array}{c}9 \\
9 \\
10\end{array}$ & 5 \\
\hline $\begin{array}{c}\text { Mill } \\
\text { Blades III }\end{array}$ & $\begin{array}{l}\text { Thickness (b) } \\
\text { Width (a) } \\
\text { Length (L) }\end{array}$ & $\begin{array}{l}19 \\
64 \\
395\end{array}$ & $\begin{array}{l}0.490 \\
0.460 \\
0.410\end{array}$ & $\begin{array}{l}0.025 \\
0.030 \\
0,032\end{array}$ & $\begin{array}{c}5 \\
19 \\
126 \\
\end{array}$ & $\begin{array}{l} \\
- \\
-\end{array}$ & $\begin{array}{c}20 \\
34 \\
141 \\
\end{array}$ & $\begin{array}{l}- \\
- \\
-\end{array}$ & $\begin{array}{c}9 \\
9 \\
11\end{array}$ & 4 \\
\hline
\end{tabular}

CNC-L: Numerical control lathes. CNC-MC: Numerical control machining centers

Table 7. Results of $D C$ and $\triangle D C$ for experimental specimens.

\begin{tabular}{|c|c|c|c|c|}
\hline \multirow{2}{*}{ Material } & \multicolumn{2}{|c|}{$D C \%$} & \multicolumn{2}{c|}{$\Delta D C \%$} \\
\cline { 2 - 5 } & Diameter (D) & Length $(L)$ & Diameter $(D)$ & Length $(L)$ \\
\hline ADI grade 2 & 0,186 & 0,158 & 0,036 & 0,026 \\
\hline ADI grade 5 & 0,347 & 0,300 & 0,027 & 0,028 \\
\hline SAE 4140 T1 & 0,051 & 0,029 & 0,060 & 0,041 \\
\hline SAE 4140 T2 & 0,062 & 0,039 & 0,043 & 0,031 \\
\hline
\end{tabular}

only influenced by $\triangle D C$. Then, the higher values of $D C$ for ADI do not imply a disadvantage for ADI, nor the smaller amounts of $D C$ imply an advantage for steel.

$\triangle D C$ values were consistently lower for $\mathrm{ADI}$ than for steel, and, as it was shown in Fig. 1-d), $\Delta D C$ is an important factor that directly affects $T m$. This indicates that the use of ADI allows to have a higher $T m$ than those obtainable when SAE 4140 steel is employed (Fig. 4). This, in fact, could lead to economic benefits in a serial production process, since ADI parts have better possibilities to satisfy $\mathrm{Tm}$, in the previous machining before the heat treatment, than steel parts. Nevertheless it is important to point out that this advantage could not be real if any variable of the process modifies the $D C$ average for ADI. For this reason, it is necessary to have under control the variables affecting $D C$.

The low value of $\triangle D C$ seems to be characteristic of ADI, since this observation has been consistently valid along the great number of measurements carried out for each type of piece, and even after significant changes in the operating variables were considered (chemical compositions, as-cast microstructures, ADI grades, and shape and size of the parts used in the present study).

\section{3. $\quad \Delta D C$ as a Decisive Factor to Determine the Fabri- cation Steps}

Taking into account the following factors: size tolerance $(T)$, machining tolerance $(\mathrm{Tm})$ and dimensional accuracy of the machining process $(D A)$, the value of $\triangle D C$ allows to decide whether the final machining operation of a part can be carried out before, or must be done after heat treatment.

When $\triangle D C$ is greater than the size tolerance $T$, the machining tolerance $T m$ disappear, and it is necessary a final machining step after heat treatment, working under worse machinability conditions.

When $\triangle D C$ is lower than the size tolerance $T$, there can be three different situations:

a) $T m$ is greater or equal than $D A$ : In this case the final machining can be made before heat treatment, making use of the best machinability conditions.

b) $T m$ is lower than $D A$ : In this case a higher precision machining procedure can be used, if available, which involves higher cost. 

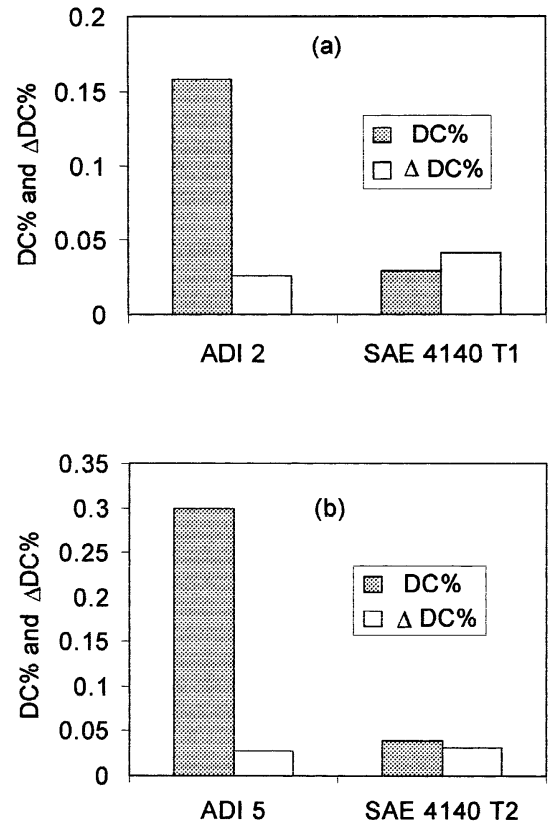

Fig. 3. $D C$ and $\triangle D C$ for the length $(L)$ of ADI and SAE 4140 steel specimens.

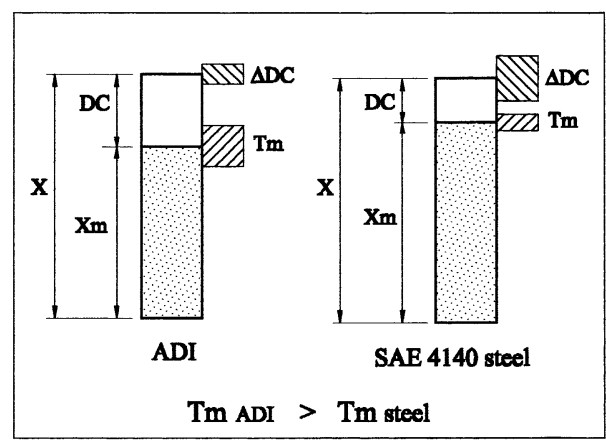

Fig. 4. Comparative values of $\triangle D C$ and $T m$ for $\mathrm{ADI}$ and $\mathrm{SAE}$ 4140 steel.

c) $T m$ is much lower than $D A$ : In this case it is impossible to reach the required tolerance, and it will be necessary to carry out the final machining step after heat treatment, working under the worse machinability conditions, and the use of grinding may be necessary.

In summary, it is desirable that $\triangle D C$ remains as lower as it is possible.

\subsection{Influence of the Previous Microstructure, Heat Treatment Variables and Anisotropy, on the $D C$ of ADI}

Table 6 shows that the internal gears, identified as I in Table 4, have lower $D C$ than the other gears. Also the disks with hub show lower $D C$ than the medium and thin disks. This implies that, for the same grade of ADI, the parts having a ferritic matrix before heat treatment show lower $D C$ than those having pearlitic matrix. Figures 5(a) and 5(b) show $D C$ of one dimension of the mentioned parts. This results are in coincidence with previous reports. ${ }^{7)}$

For the same previous microstructure the $D C$ for specimens of ADI grade 2 was lower than that of ADI grade 5 ones. The same behavior was observed for the $D C$ of the industrial parts reported on Table 6. Note, for example, that (a)

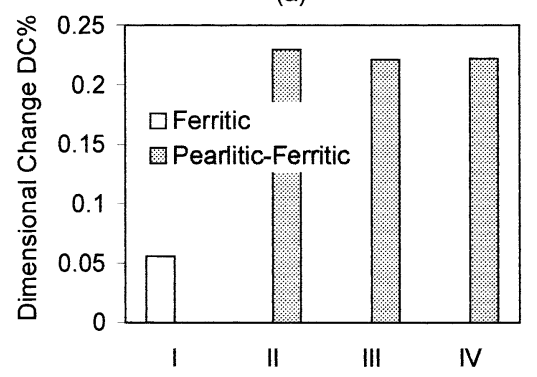

(b)

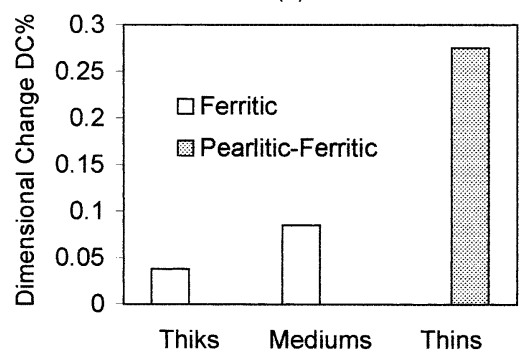

Fig. 5. Effect of previous microstructure on $D C$ : 5-a, dimension $(D)$ of internal gears; 5-b, dimension $\left(D_{1}\right)$ of disks with hub.

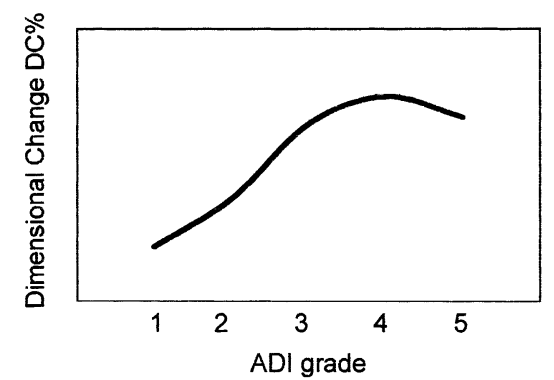

Fig. 6. Influence of $\mathrm{ADI}$ grade on $D C$ (qualitative scheme).

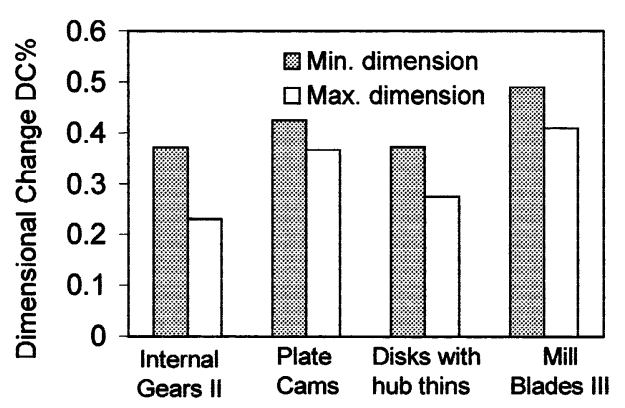

Fig. 7. Anisotropic behavior of $D C$.

the medium disks with hubs made in ADI grade 1 show lower $D C$ than the plate cams of ADI grade 3. A similar comparison can be done for the mill blades I and II of ADI grades 4 and 5 respectively. This results are also in coincidence with other studies, as it is shown in Fig. 6. ${ }^{7,9)}$

Comparing the $D C$ values of all the industrial parts indicated in Table 6 and Fig. 7, it is clear that the smaller the measured dimension, the higher the value of $D C$. This results also confirm a similar tendency observed by the authors in a previous work, were this anisotropy was found to be maximum for very different dimensions located in or- 
thogonal directions. ${ }^{7,9)}$

\section{Conclusions}

(1) Typically, ADI parts suffer larger $D C$ than SAE 4140 steel parts of similar mechanical properties. On the other hand, the standard deviation values of the dimensional change $(\triangle D C)$ were always lower for ADI than for steel.

(2) The low value of $\triangle D C$ seems to be characteristic of ADI, since this observation has been consistently valid along the great number of measurements carried out for each type of piece, and even after significant changes in the operating variables were considered.

(3) Being $\triangle D C$ an important factor that directly affects $T m$, the use of ADI allows to have a higher Tm than those necessary when SAE 4140 steel is employed. This, in fact, could lead to economic benefits in a serial production process, since ADI parts have better possibilities to satisfy $T m$, in the previous machining before heat treatment.

(4) The results of this study confirm previous reports referred to the influence that the prior microstructure, the austempering temperature and the piece anisotropy, exert on the $D C$ of ADI.

\section{Acknowledgements}

Financial support received from FONCYT (grant 1252) and from the National University of Mar del Plata and CONICET, are gratefully acknowledged.

\section{REFERENCES}

1) Metals Handbook, Ninth Edition, Vol. 4, ASM, Metals Park, OH, (1981).

2) J. Dodd and R. Gundlach: Proc. of the BCIRA Conf. for Future Prosperity, Climax Mo Co., Vol. XV, Arlington Heights, IL, (1984), $1-21$.

3) J. R. Keough: AFS Proc. of the 3rd World Conf. on ADI (USA), Vol. II, AFS, Des Plaines, IL, (1991), 638-658.

4) R. Gundlach, J. Janowak, S. Bechet and K. Rohrig: Proc. of Mat. Res. Soc. Symp., Vol. 34, AMAX, Ann Arbor, MI, (1985), 399-409.

5) N. S. Chang, C. Grupke, J. M. Tarajos and G. M. Dahl: Proc. of the 1991 World Conf. on Austempered Ductile Iron, AFS, Des Plaines, IL, (1991), 271-272.

6) O. J. Moncada, R. H. Spicacci and J. A. Sikora: AFS Transactions, 106 (1998), 39-46.

7) O. J. Moncada and J. A. Sikora: AFS Transactions, 104 (1996), $577-$ 580.

8) International Standard ISO 286-2, ISO System of Limits and Fits, (1988) (E).

9) M. D. Echeverría and O. J. Moncada: Dispersión de la variación dimensional en piezas de ADI, Anales SAM Rosario (Argentina), IBEROMET V, Universidad Nacional de Rosario, Córdoba, (1998), $287-290$. 